\title{
EFEKTIFITAS PELATIHAN KETERAMPILAN OLAH PANGAN PADA KELOMPOK IBU MENYUSUI TERHADAP PENUNJANG KEBERHASILAN LAKTASI
}

\author{
Diyan Indriyani ${ }^{1}$, Awatiful Azza ${ }^{2}$ \\ Fakultas Ilmu Kesehatan Universitas Muhammadiyah Jember ${ }^{1,2}$ \\ email. diyanindriyani@unmuhjember.ac.id
}

\begin{abstract}
Babies are one group that has health risks. To reduce thus risk, one of them is by optimizing the nutritional needs for the baby. Breast Milk is the primary food for babies, especially when they are 0-6 months old. This condition becomes very important that breastfeeding mothers must have good quality of breast milk. However, the fact therewere still many experiences that increasing the quantity and quality of breast milk is not optimal yet. The purpose of this research was to analyze the effectiveness of food processing skills training on breastfeeding mothersgroupto support the lactation success. Respondents in this research were 12 breastfeeding mothers who lived in Purwojati and Dukuh, Dukuhdempok Village, Wuluhan, Jember. Research design of this research is Pre-Experiment with intervention of food processing skills training using catfish as basic ingredients. Instrument which used was food processing SOP for breastfeeding mothers and likert scale. The research results using the Dependent $T$-Test analysis showed that on the topic of nutrition management in the lactation period, the pretest mean score was 62.5 and the mean score of the posttest was 76.25 with P-Value 0.00. The conclusion of this researchthatfood processing skills training on breastfeeding mothers groups to support the lactation success was effective. As a recommendation, the health workers and families should give motivation for breastfeeding mothers to improve their food processing skills, which varies, especially with catfish as basic ingredients to increase appetite in order o to support lactation success.
\end{abstract}

Keyword: BreastMilk, Breastfeeding, Food Processing

\section{PENDAHULUAN}

Bayi merupakan salah satu kelompok yang memiliki risiko kesehatan. Untuk mengurangi risiko tersebut salah satunya dengan mengoptimalkan kebutuhan nutrisi bagi bayi Air Susu Ibu (ASI) merupakan makanan utama bagi bayi terutama saat berusia 0-6 bulan. Kondisi ini menjadi sangat penting bahwa ibu menyusui harus memiliki kualitas ASI yang baik, karena makanan bayi tersebut sangat tergantung dari makanan ibu yang membentuk kualitas ASI. Bila kualitas ASI baik, maka sangat dimungkinkan ibu bisa memberikan ASI secara eksklusif, yaitu bayi hanya diberi ASI saja sampai usia 6 bulan (Hamilton, 2010).

Namun kondisi pemberian ASI eksklusif ini kadang masih mengalami kendala, karena kualitas ASI yang tidak mendukung untuk dapat dipertahankan sampai batas waktu 6 bulan. Selain itu ibu menyusui kadang masih belum memiliki pemahaman yang optimal dalam mengelola ASI dan meningkatkan kualitas ASI, yang salah satunya dengan penunjang berupa nutrisi yang memadai dan syarat akan 
gizi (Indriyani, Asmuji dan Wahyuni, 2016). Data identifikasi menunjukkan bahwa cakupan ASI eksklusif di wilayah Mitra masih tergolong rendah, yaitu di Dusun Purwojati hanya 32\% dan di Dusun Dukuh hanya sebesar 37\%. Jumlah cakupan ASI eksklusif ini sangat jauh dari harapan pemerintah (Dinas Kesehatan Kabupaten Jember, 2015). Menurut Anggorowati dan Nuzulia (2013) bahwa kondisi rendahnya cakupan ASI eksklusif ini salah satu faktornya adalah ketidakcukupan ASI dan ibu menyusui kurang mampu mempertahankan ASI dalam memenuhi kebutuhan bagi bayi usia 0-6 bulan atau lebih.

Responden merupakan kelompok ibu menyusui yang tinggal di wilayah Dusun Purwojati dan Dusun Dukuh, Desa Dukuhdempok Kecamatan Wuluhan Kabupaten Jember yang sebagiannya memiliki kebiasaan selama menyusui mengkonsumsi makanan sederhana, kurang bervariasi, komposisi gizi belum berimbang terutama yang mengandung unsur protein masih cenderung mayoritas menggunakan protein nabati dalam unsur gizinya seperti tahu tempe karena merasa aman, dan hanya cenderung digoreng saja. Responden juga belum memiliki keterampilan serta pengetahuan yang optimal dalam hal bagaimana mengolah bahan makanan sumber protein tinggi dari bahan dasar yang bersifat mudah didapat, murah serta mengandung unsur protein tinggi yang sangat diperlukan bagi ibu menyusui, salah satunya yaitu bahan dasar misalnya ikan lele. Sementara pada masa menyusui sangat diperlukan semua unsur gizi secara seimbang, salah satunya adalah unsur protein.

Dampak dari ketidakseimbangan nutrisi pada masa menyusui ini secara umum dapat mengakibatkan masalah kesehatan bagi bayi. Bila kesehatan bayi terganggu maka akan sangat berisiko adanya kondisi sakit pada bayi bahkan bisa sampai terjadi risiko kematian (Indriyani dan Azza, 2017). Oleh karena itu sangat diperlukan adanya solusi yang mengarah kepada terwujudnya kualitas ASI, dengan cara meningkatkan pemahaman tentang keterampilan dalam mengolah bahan makanan sumber protein untuk menunjang kualitas ASI dengan bahan dasar yang mudah dan murah didapat misalnya salah satunya adalah bahan dasar ikan lele. Kelebihan ikan lele adalah selain mudah didapat serta murah, lele memiliki cita rasa yang lezat, tinggi protein dan asam amino omega 3, rendah lemak, mengandung kadar fosfor, magnesium,zink, kalsium, zat besi dan kalium cukup tinggi ( porsi ikan lele mengandung 15,6 gram protein), sumber vitamin B12 (porsi lele sudah memenuhi kebutuhan $40 \%$ vitamin B 12), rendah merkuri, sehinga sangat tepat diberikan untuk ibu yang sedang menyusui juga dapat sebagai penunjang penyembuhan luka bagi ibu menyusui karena dampak dari persalinan (Alodokter, 2015). Berdasarkan paparan di atas maka perlu diberikan pelatihan tentang keterampilan olah pangan pada ibu menyusui guna menunjang keberhasilan laktasi.

\section{METODE PENELITIAN}

Penelitian ini merupakan penelitian kuantitatif menggunakan PraExperiment Pre-Posttest Design. Tehnik pengumpulan data menggunakan SOP 
olah pangan bagi ibu menyusui dan skala likert. Jumlah sampel yang digunakan yaitu 12 ibu menyusui di Dusun Purwojati dan Dusun Dukuh Desa Dukuhdempok Kecamatan Wuluhan Jember dengan pengambilan saml secara Purposive Sampling yang dimulai pada bulan Mei 2018. Analisis data menggunakan Dependet T-test.

\section{HASIL DAN PEMBAHASAN}

Kegiatan penelitian ini difokuskan pada kelompok ibu menyusui yang ada di wilayah Dusun Purwojati dan Dusun Dukuh, Desa Dukuhdempok Kecamatan Wuluhan Kabupaten Jember yang menghadapi masalah upaya peningkatan kualitas ASI. Pelatihan bagi kelompok ibu menyusui tim pelaksana melakukan pada hari Minggu tanggal 20 Mei 2018. Pelatihan ini juga dilaksanakan mulai jam 09.0012.00 WIB. Topik yang dibahas pada pelatihan ini adalah tentang keterampilan olah pangan dalam meningkatkan kualitas ASI. Sebelum dan sesudah dilakukan pelatihan kelompok ibu menyusui diukur kemampuan melakukan keterampilan olah pangan yang berbahan dasar lele. Metode pelatihan yang dilakukan dalam bentuk ceramah, demonstrasi dan redemonstrasi. Di bawah ini terlihat pada gambar 1 tentang kegiatan pelatihan keterampilan olah pangan pada kelompok ibu menyusui:

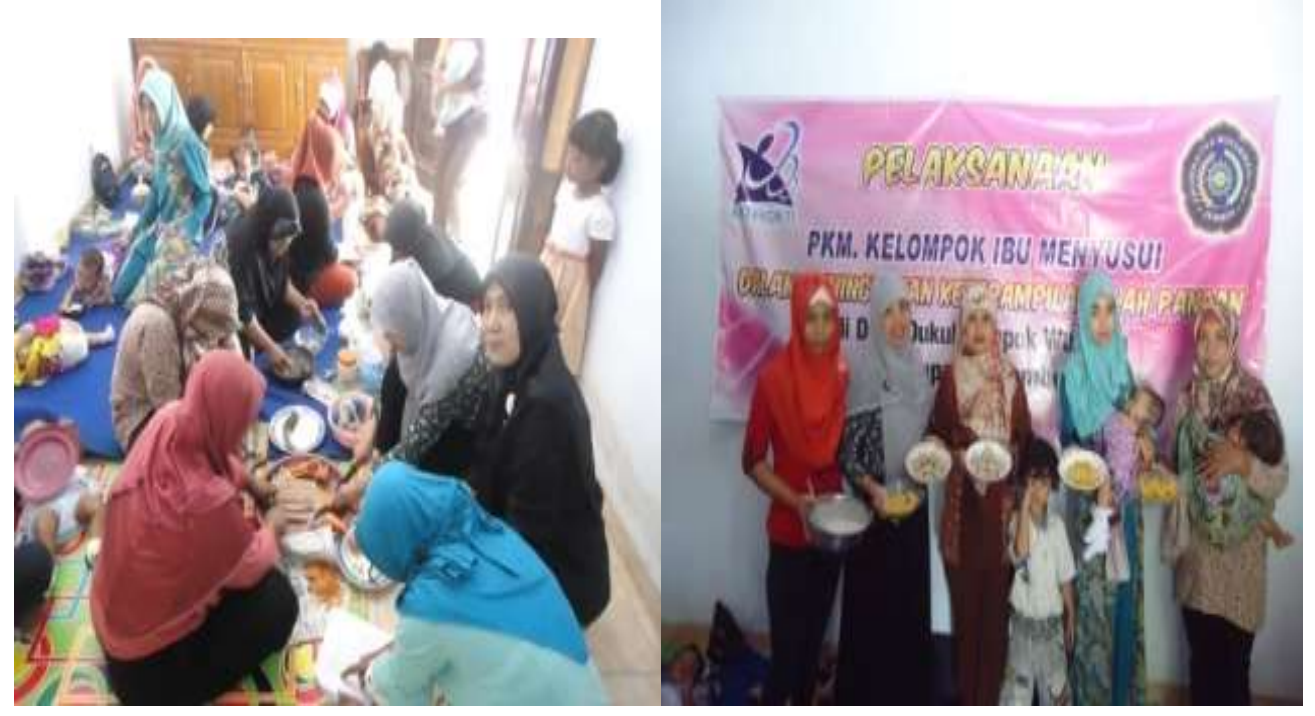

Gambar 1. Pelatihan (Keterampilan Olah Pangan)

Hasil pelatihan keterampilan olah pangan ini dapat terlihat pada tabel $1 \mathrm{di}$ bawah ini:

Tabel 1 Distribusi Frekuensi Usia Kelompok Ibu Menyusui di Dusun Purwojati dan Dukuh Desa Dukuhdempok Kec. Wuluhan Jember Tahun 2018. n=12

\begin{tabular}{ccc}
\hline Usia & Jumlah & Prosentase \\
\hline$<20$ Tahun & 1 & 8.3 \\
20-35 Tahun & 11 & 91.7 \\
$>35$ Tahun & 0 & 0.0 \\
\hline Total & 12 & 100.0
\end{tabular}


Terlihat pada tabel 1 bahwa mayoritas ibu menyusui di di Dusun Purwojati dan Dukuh Desa Dukuhdempok Kec. Wuluhan Jember memiliki usia 20-35 tahun yaitu sebanyak 11 responden $(91,7 \%)$

Tabel 2 Distribusi Frekuensi Pendidikan Kelompok Ibu Menyusui di Dusun Purwojati dan Dukuh Desa Dukuhdempok Kec. Wuluhan Jember Tahun 2018. $\mathrm{n}=12$

\begin{tabular}{ccc}
\hline Pendidikan & Jumlah & Prosentase \\
\hline SD-SMP & 2 & 16.7 \\
SMA & 10 & 83.3 \\
PT & 0 & 0.0 \\
\hline Total & 12 & 100.0 \\
\hline
\end{tabular}

Merujuk pada tabel 2 bahwa mayoritas ibu menyusui di di Dusun Purwojati dan Dukuh Desa Dukuhdempok Kec. Wuluhan Jember memiliki pendidikan SMA yaitu sebanyak 10 responden $(83,3 \%)$

Tabel 3 Distribusi Frekuensi Pekerjaan Kelompok Ibu Menyusui di Dusun Purwojati dan Dukuh Desa Dukuhdempok Kec. Wuluhan Jember Tahun 2018. $\mathrm{n}=12$

\begin{tabular}{ccc}
\hline Pekerjaan & Jumlah & Prosentase \\
\hline Ibu Rumah Tangga & 12 & 100 \\
\hline Total & 12 & 100.0 \\
\hline
\end{tabular}

Melihat pada tabel 3 bahwa keseluruhan ibu menyusui di di Dusun Purwojati dan Dukuh Desa Dukuhdempok Kec. Wuluhan Jember memiliki pekerjaan ibu rumah tangga yaitu sebanyak 12 responden $(100 \%$

Tabel 4 Efektifitas Pelatihan Keterampilan Olah Pangan Terhadap Penunjang Keberhasilan Laktasi pada Kelompok Ibu Menyusui di Dusun Purwojati dan D Dukuhukuh Desa dempok Kec. Wuluhan Jember Tahun 2018. $\mathrm{n}=12$

\begin{tabular}{lrrrrrr}
\hline Variabel & Min & \multicolumn{1}{c}{ Max } & Mean & Standar Deviasi & SE Mean & P value \\
\hline Pretest & 45 & 65 & 57.08 & 7.217 & 2.083 & \multirow{2}{*}{0.00} \\
\cline { 1 - 5 } Posttest & 70 & 85 & 77.08 & 4.502 & 1.300 & \\
\hline
\end{tabular}

Berdasarkan tabel 4 pada kegiatan pelatihan pada kelompok ibu menyusui tersebut didapatkan bahwa kemampuan keterampilan olah pangan sebelum pelatihan (pretest) memiliki nilai rerata (Mean) 57,08, dapun nilai mean setelah pelatihan (posttest) didapatkan nilai 77,08. Hasil ukur pengaruh pelatihan terhadap penunjang keberhasilan lakatasi didapatkan nilai $\mathrm{p}$ ( $p$ value) sebesar 0,00 yang artinya pelatihan keterampilan olah pangan terhadap penunjang keberhasilan laktasi pada kelompok ibu menyusui efektif. 
Kelompok ibu menyusui sangat responsif dalam mengikuti pelatihan, terbukti saat melakukan redemonstrasi olah pangan yang berbahan dasar lele, peserta dapat mendemonstrasikan sesuai arahan yang telah disampaikan. Bila dilihat dari hasil analisis data tersebut di atas bahwa pelatihan ini memiliki dampak yang positif dalam meningkatkan kemampuan ibu menyusui dalam melakukan variasi menu makanan sebagai asupan nutrisi sehari-hari selama periode menyusui.

Faktor yang kadang masih menjadi kendala bagi ibu menyusui dalam menyiapkan kualitas ASI yang baik antara lain adalah pemahaman yang belum optimal dalam hal manajemen laktasi termasuk di dalamnya adalah yang berkaitan dengan nutrisi masa kehamilan. Selain itu juga kadang measih dipengaruhi oleh kultur yang berkembang di masyarakat sebagai keyakinan perilaku yang merasa harus dijalankan. Keterampilan olah pangan dalam menyiapkan gizi seimbang selama laktasi juga merupakan hal yang sangat penting. Kelompok ibu menyusui yang sudah memiliki kemampuan tersebut di atas, maka akan berdampak kemampuan oleh pangan menjadi meningkat, lebih bervariasi dalam menyediakan sajian nutrisi, sehingga motivasi konsumsi yang mengandung komponen penting terutama protein bisa meningkat.

Salah satu kompetensi yang dicapai dalam kegiatan penelitian menggunakan pendekatan Pra Experiment Pre-Posttest Design ini adalah ibu kelompok menyusui memiliki penambahan keterampilan mengolah makanan terutama yang berbahan dasar lele. Lele ini menjadi bahan dasar yang dipilih karena memiliki banyak kelebihan dan kemudahan. Menurut Alodokter (2015) makanan yang berasal dari bahan dasar ikan lele. bahan dasar ini dipilih dengan alasan selain gurih, lele merupakan bahan dasar yang mudah didapat, murah dan digemari masyarakat, serta mengandung unsur gizi yang baik. Unsur gizi tersebut terutama tinggi protein, dan asam amino omega 3, rendah lemak, mengandung kadar fosfor, magnesium,zink, kalsium, zat besi dan kalium cukup tinggi (porsi ikan lele mengandung 15,6 gram protein), sumber vitamin B12 (porsi lele sudah memenuhi kebutuhan $40 \%$ vitamin B 12), rendah merkuri, sehinga sangat tepat diberikan untuk ibu yang sedang menyusui juga dapat sebagai penunjang penyembuhan luka bagi ibu menyusui karena dampak dari persalinan. Tim peneliti melakukan pelatihan keterampilan olah pangan bagi kelompok ibu menyusui dengan bahan dasar tersebut menjadi contoh menu 5 jenis hasil olahan yaitu: a) nugget lele, b) lele fillet goreng tepung, c) lele rempah kelapa daun kunyit, d) lele kuning asam pedas dan e) lele panggang nusantara. Jenis-jenis menu ini menjadi sajian menu yang lezat dan dapat meningkatkan selera makan yang bergizi. Menurut Indriyani, Asmuji dan Wahyuni (2016) dikatakan bahwa pada masa menyusui, sangat diperlukan nutrisi yang tepat agar terpenuhi unsur gizi yang dibutuhkan oleh bayi. Nutrisi ibu menyusui harus memenuhi seluruh unsur gizi secara seimbang. Kualitas ASI dan ASI sangat tergantung dari nutrisi ibu pada masa laktasi.

Aktifitas ini memiliki sinergisme dengan program kesehatan ibu dan anak (KIA) yang memiliki tujuan akhir (outcome) untuk mendukung penurunan angka 
kematian bayi. Banyak faktor yang menjadi penunjang kematian bayi, salah satunya karena terjadinya kondisi sakit bahkan mengancam keselamatan yang disebabkan karena salah satu faktor misalnya malnutrisi. Bayi dengan usia 0-6 bulan, sebagai kelompok yang berisiko kesehatan, merupakan mahluk yang sangat tergantung dari pola asuh orangtua terutama ibu dalam menyediakan kecukupan gizi. Hal ini karena bayi merupakan kelompok usia yang tergantung penuh terhadap orangtua. ASI sebagai makanan yang paling utama dan satu-satunya bagi bayi usia 0-6 bulan, harus disiapkan dengan kualitas dan kuantitas yang memadai. Hal ini karena kualitas dan kuantitas ASI sangat tergantung dari makanan yang dikonsumsi oleh ibu di masa laktasi. Apabila ibu menyusui memiliki kemampuan optimal dalam menyediakan menu yang dikonsumsi sehari-hari pada masa laktasi, maka akan didapatkan peluang kecukupan terhada konsumsi selama menyusui lebih baik. Selain itu, menyusui dapat menjadi suatu aktifitas yang menyenangkan bagi ibu, selain meningkatnya kualitas hubungan ibu-bayi dalam menjalankan peran dan fungsinya sebagai orangtua. Penelitian oleh Umboh, Wilar dan Mantik (2013) mendapatkan hasil adanya hubungan yang signifikan antara pengetahuan manfaat ASI dengan keberhasilan menyusui. Berkaitan dengan penelitian ini, maka dapat dipaparkan juga bahwa guna berhasilnya pemberian ASI pada bayi, pengetahuan ibu yang menunjang hal-hal terkait laktasi sangatlah penting.

\section{KESIMPULAN}

1. Kemampuan keterampilan olah pangan pada kelompok ibu menyusui di Dusun Purwojati dan Dukuh Desa Dukuhdempok Kecamatan Wuluhan Jember sebelum pelatihan (pretest) memiliki nilai rerata (Mean) 57,08.

2. Kemampuan keterampilan olah pangan pada kelompok ibu menyusui di Dusun Purwojati dan Dukuh Desa Dukuhdempok Kecamatan Wuluhan Jember setelah pelatihan (posttest) didapatkan nilai 77,08.

3. Hasil ukur pengaruh pelatihan terhadap penunjang keberhasilan laktasi didapatkan nilai $\mathrm{p}$ ( $p$ value) sebesar 0,00 yang artinya pelatihan keterampilan olah pangan terhadap penunjang keberhasilan laktasi pada kelompok ibu menyusui efektif.

\section{UCAPAN TERIMAKASIH}

1. Direktorat Riset dan Pengabdian Kepada Masyarakat. Kementerian Riset, Teknologi, dan Pendidikan Tinggi yang telah mendanai kegiatan ini.

2. Rektor Universitas Muhammadiyah Jember beserta seluruh Civitas Academika

3. Lembaga Penelitian dan Pengabdian Masyarakat (LPPM) Universitas Muhammadiyah Jember 
4. Kelompok ibu menyusui di Dusun Purwojati dan Dukuh Desa Dukuhdempok Kecamatan Wuluhan Jember

\section{DAFTAR PUSTAKA}

Anggorowati \& Nuzulia, F. (2013). Hubungan antara Dukungan Keluarga dengan Pemberian ASI Eksklusif pada Bayi di Desa Bebengan Kecamatan Boja Kabupaten Kendal. Jurnal Keperawatan Maternitas Vol. 1 No.1; 1-8

Alodokter. (2015). Tidak Sedikit Manfaat Ikan Lele. www.alodokter.com

Dinas Kesehatan Kabupaten Jember. (2015). Laporan Tahunan Dinas Kesehatan Kabupaten Jember.

Hamilton, P.M. (2010). Dasar-dasar Keperawatan Maternitas. Edisi 7. Alih Bahasa: Asih, G.Y. Jakarta: EGC

Indriyani D., Asmuji. Dan Wahyuni, S., (2016). Edukasi Postnatal dengan Pendekatan Family Centered Maternity Care (FCMC). Yogyakarta: Trans Medika

Indriyani D. dan Azza, A. (2017). Survey perilaku konsumsi nutrisi pada ibu menyusui dan ASI Ekslusif di Kabupaten Jember. LPPM. Universitas Muhammadiyah Jember

Umboh, E., Wilar, R dan Matik, F.X.J. (2013). Pengetahuan Ibu Mengenai Manfaat ASI Pada Bayi. Jurnal e-Biomedik (eBM), Volume 1, Nomor 1, Maret 2013, hlm. 210-214. http://download.portalgaruda.org. 